\section{Monocytic and Monomyelocytic Leukaemia with Increased Serum and Urine Lysozyme as a Late Com- plication in Plasma Cell Myeloma}

\section{ELLIOTT F. OSSERMAN}

Monocytic or monomyelocytic leukaemia has developed as a late and terminal complication in three of our cases of multiple myeloma after the prolonged chemotherapeutic suppression of the multiple myeloma (see Table).

\begin{tabular}{cr|c|c|c|c}
\hline Case and Sex & $\begin{array}{c}\text { Age at } \\
\text { Onset of } \\
\text { Multiple } \\
\text { Myeloma }\end{array}$ & M-Protein & $\begin{array}{c}\text { Duration of Multiple } \\
\text { Myeloma Before the } \\
\text { Leukaemia (years) }\end{array}$ & Therapy \\
\hline 1 & $M$ & 41 & Bence Jones & 4 & $\begin{array}{c}\text { Radiotherapy, } \\
\text { urethane, and } \\
\text { melphalan } \\
\text { Melphalan, } \\
\text { androgen } \\
\text { Melphalan, } \\
\text { cyclophos- } \\
\text { phamide } \\
\text { androgen }\end{array}$ \\
\hline
\end{tabular}

The relatively young age of onset of multiple myeloma in all three cases is noteworthy. Case 3 was in fact the youngest patient in our experience with over 400 cases of multiple myeloma. In all three cases the clinical and haematological features of the leukaemia appeared abruptly and terminated fatally within one to two months. Nevertheless, in Cases 2 and 3 there were transient episodes of fever and leucocytosis with relative monocytosis for several months preceding the final florid leukaemic phase. Increasing proportions of monocytes and monoblasts were also recorded in the bone marrows of these cases during the preleukaemic periods.

In all three cases the multiple myeloma had been exceptionally well suppressed by continuous chemotherapy for the periods shown in the Table. Chemotherapy for the multiple myeloma had been discontinued 2, 10, and 18 months, respectively, in the three cases before the emergence of the monomyelocytic leukaemic phase because of evidence of bone marrow failure. There was no evidence of recrudescence of the multiple myeloma in any of these cases during the later preleukaemic and leukaemic phases. Moreover, the myelomonocytic leukaemia was consistently associated with appreciable increases in serum and urine lysozyme (muramidase) levels. There was also evidence of renal tubular dysfunction secondary to lysozyme overloading ("lysozyme nephropathy")-that is, hypokalaemia, hyperkaluria, and "tubular" proteinuria.

It is postulated that the development of monomyelocytic leukaemia in these cases of multiple myeloma is related to the functional interrelationship between monocytes (histiocytes) and plasma cell in the processing of antigen and in the formation of antibody. The possibility that the preceding myeloma chemotherapy may have contributed to the ultimate development of a monocytic dyscrasia cannot be excluded, but if the chemotherapy did, in fact, contribute to the development of leukaemia it was a "reasonable price" to pay for the prior benefits derived.

Institute of Cancer Research and Department of Pathology, College of Physicians and Surgeons, Columbia University, New York, N.Y. 10032

ELLIOTT F. OSSERMAN

\section{Extramedullary Plasmacytoma}

\section{E. WILTSHAW}

Despite the widespread distribution of plasma cells throughout the body, plasma-cell tumours most commonly occur within the bone marrow and only rarely present in extramedullary sites. A study of 266 cases of extramedullary plasmacytoma has shown that $75 \%$ present in the submucosa of the upper air passages and that many are apparently multifocal. The mode of spread resembles that of reticulum-cell sarcoma and is characterized by early invasion of lymph nodes draining the primary site, followed by blood borne metastases to bones, subcutaneous tissues, and other organs.

Even when the disease is widespread, the bone marrow is rarely affected and as a result large doses of chemotherapy with alkylating agents may be given safely. In most cases this treatment is followed by dramatic and sometimes prolonged remissions, and in two instances complete healing of bone metastases has been seen.

On the other hand, the findings in a study of 77 cases of solitary myeloma of bone confirm that in regard to age at presentation, mode of spread within skeletal bone marrow, and the lack of extramedullary lesions-even in advanced disease-solitary myeloma of bone is a rare form of presentation of myelomatosis and not a separate entity.

\begin{tabular}{l|c|c}
\hline & $\begin{array}{c}\text { Extramedullary } \\
\text { Plasmacytoma }\end{array}$ & $\begin{array}{c}\text { Solitary Myeloma } \\
\text { of Bone }\end{array}$ \\
\hline $\begin{array}{l}\text { Age at presentation (years) } \\
\text { range } \\
\text { and median }\end{array}$ & $\begin{array}{c}8-52 \\
51-60\end{array}$ & $\begin{array}{c}14-72 \\
51-60\end{array}$ \\
\hline Presenting site & $\begin{array}{c}\text { Upper air passages in } \\
75 \% \text { of cases }\end{array}$ & $\begin{array}{c}\text { A vertebra 20\%; pelvis } \\
20 \% \text {; femur } 20 \% \text { (40\% } \\
\text { showed a trabeculated } \\
\text { lesion) }\end{array}$ \\
\hline Dissemination & $\begin{array}{c}\text { Bone deposits 40.5\% } \\
\text { Bone and soft tissue } \\
\text { deposits 40.5\%. } \\
\text { tissue deposits only } \\
19 \%\end{array}$ & $\begin{array}{l}\text { By widespread involve- } \\
\text { ont of areas of active } \\
\text { haemopoiesis. }\end{array}$ \\
$\begin{array}{c}\text { Bone deposits only 100\% } \\
\text { Myeloma cells found on } \\
\text { marrow aspiration }\end{array}$ & $\begin{array}{c}10 \% \text { of cases with dis- } \\
\text { seminated disease }\end{array}$ & $\begin{array}{c}\text { All cases with dissemi- } \\
\text { nated disease }\end{array}$ \\
\hline
\end{tabular}

Royal Marsden Hospital, Fulham Road, London S.E.3

E. WILTSHAW

\section{Prognostic Factors in Myelomatosis}

\section{BO JOHANSSON}

Since 1930 a total of 271 patients with myeloma have been seen at the Radiumhemmet in Stockholm. Of these, 142 were seen before 1960 and were treated with palliative radiotherapy; the remaining 129 were treated mainly with cytotoxic drugs, and their survival rate was about three times higher than in the earlier group. As well as the later treatment being more effective there may be other explanations for this improvement in survivalsuch as earlier and more frequent diagnosis and differences in the types of patients referred to the hospital during different periods of time.

An attempt was made to see whether the heterogenous group of patients with multiple myeloma treated with cytotoxic drugs could be subdivided into subgroups with different prognosis. 